Jahangirnagar University J. Biol. Sci. 4(1): 1-7, 2015 (June)

\title{
Prevalence and intensity of helminth parasites in the snake headed fish, Channa punctatus of Savar, Dhaka
}

\author{
Sabira Sultana* and Md. Abdus Salam \\ Department of Zoology, Jahangirnagar University, Savar, Dhaka-1342, Bangladesh.
}

\begin{abstract}
Ten species of helminth parasites i.e. Neopecoelina saharanpuriensis, Mesolecitha linearis, Asymphylodora tincae, Genarchopsis bangladensis, Ditestolepis diphana, Senga sp., Neoechinorhynchus tylosuri, Pallisentis sp., Ascardia larvae., Gnathostoma spinigerum were identified from Channa punctatus of Savar area. Majority of the parasites were found in the intestine. The overall prevalence of infection of the parasites was $32.5 \%$ and the mean intensity was $1.46 \pm 1.29$. Both the prevalence $(34.61 \%)$ and mean intensity $(1.5 \pm 1.21)$ were higher in male fishes than the female fishes $(28.57 \%$ and $1.375 \pm 0.99$ respectively). The prevalence $(13.75 \%)$ and mean intensity $(1.64 \pm 0.67)$ of trematodes were the highest among the parasites groups. Both the prevalence and mean intensity were the highest in the intermediate length $(10.1-15.1 \mathrm{~cm})$ and weight $(21-31 \mathrm{gm})$ groups of fishes.
\end{abstract}

Key words: Channa punctatus, helminth parasite, prevalence and intensity

\section{INTRODUCTION}

Parasites occupy definite position in the animal kingdom for their remarkable adaptations and damaging activities to the host. The importance of parasite is related directly to the fish that may affect the general public health (Hoffman, 1967). Every parasite living in or on a fish extents some degree of harmful influence on its host. The normal growth of fish is interrupted or inhibited if they are heavily infected with parasites. The composition of the parasites of fish depends on various environmental factors such as physico-chemical factors of the water, geographical location of the habitat, season of the year, the fauna present in and around the habitat etc.

Cheng (1973) stated that the irritating activities and damages of host's tissue lining, the walls of intestine, stomach, bile duct, liver etc. by the parasites, causes microscopic lesions in the host tissue which become the site for secondary infection by the bacteria. Frequency of infestation and distribution of parasites within different organs of fishes are influenced by age and diet, abundance of parasites within the fish and their abundance (Rahman \& Parween, 2001).

According to Gupta (1983), injury of fishes can carry heavy infection of parasites that cause deterioration in the food of fish and may even result in their mortality. Besides, there are a number of helminth parasites which are transmitted to man only through fishes. The similarity in parasitic fauna between species utilizing similar food was also noted (Dogiel, 1964). The difference in feeding habits has considerable impact on

\footnotetext{
* Corresponding author. Email: dina4rm@yahoo.com
} 
intestinal parasites, but related species living together are likely to share a similar array of ectoparasites inspite of their differences.

Parasitic infestation has harmful influence on fish health that inhibits the normal growth of the hosts and may outbreaks high mortalities. The declination of Channa punctatus is regarded as its susceptibility to Epizootic Ulcerative Syndrome disease (Harris et al., 1992) and over exploitation and habitat degradation (Hussain, 2010). Studies on the Channa punctatus have so for been done mainly on the breeding program of this fish ( Srivastava \& Singh, 1994) and histopathology of diseased fish (Chandra, 1998; Afroz et al., 1999). Infestation of helminth parasites and histopathological changes in snake headed fishes was reported by Chowdhury, 1992. The morphology of Genarchopsis dasus parasites infesting Channa punctatus was described by (Banerjee, 1992) and seven parasitic species as well as Genorchopsis bangladeshensis of Channa punctatus was identified in Bangladesh where fishes were collected from hatchery and sewage lagoon (Alam et al., 2010).

Study of parasites of this fish is scanty in Bangladesh though several attempts have been taken to explore the parasitic fauna of fishes of this country (Rahman, 1989; Khan, 1985; Ahmed \& Rouf, 1981). Thus the main purpose of the present study was determined to assess the prevalence and intensity of helminth parasites of Channa punctatus collected from Savar area, Bangladesh.

\section{MATERIALS AND METHODS}

A total of 80 fish samples Channa punctatus were collected from different fish markets in Savar, Dhaka at regular interval from January, 2013 to August, 2013. Host fishes were brought to the laboratory of Zoology Department, Jahangirnagar University for detailed investigations. Sexes of the hosts were identified according to body color, bulged-out bellies, genital pore and internal gonad. The total length of host fishes were measured by using centimeter scale and divided into three length groups (viz.: $5-10 \mathrm{~cm}, 10.1-15.1 \mathrm{~cm}$, 15.2-20.2 cm).For the collection of helminth parasites the organs like body cavity, liver, stomach, intestine etc. were separated and examined under steroscopic Olympus dissecting microscope. The collected parasites were first washed in physiological saline solution and thereafter were fixed in alcohol-formaline-acetic acid (AFA), stained in borax-carmine and cleared in lectophenol (Cable, 1977). The parasites were identified according to Yamaguti $(1958,1963)$. Finally, the prevalence and mean intensity of helmith parasite of each species identified were calculated after Margolis et al. (1982). Statistical data were analysed by means \pm SDs of five replications and by using SPSS 11.5.

\section{RESULTS AND DISCUSSION}

During the study period, a total of 38 parasites were collected from Channa punctatus. Ten species of helminth parasites belonging to different groups were identified from different organ of the host body. Among them four species were trematode, Neopecoelina saharanpuriensis (Gupta, 1953), Mesolecitha linearis (Linton, 1910), Asymphylodora 
tincae (Modeer, 1790), Genarchopsis bangladensis (Bashirullah \& Elahi, 1972), two species were cestodes, Ditestolepis diphana (Cholodk, 1906), Senga sp. (Dolifus, 1934), two species were acanthocephalans Neoechinorhynchus tylosuri (Yamaguti, 1939), Pallisentis sp. (Sarkar, 1953) two species were nematodes Ascardia sp. ( Duj, 1845), Gnathostoma spinigerum (Owen, 1836).

The prevalence of infestation was $32.5 \%$ and the mean intensity of infestation was 1.46 \pm 1.29 . The prevalence of infestation in male and female hosts was $34.61 \%$ and $28.57 \%$ respectively (Table 1$)$. The mean intensity was slightly higher in males $(1.5 \pm 1.21)$ than in females $(1.375 \pm 0.99)$. The present study revealed that both the prevalence and intensity were highest in male than in female (Table 1). It was revealed that male hosts were observed to be more infected than females. Akther (1995) also showed the same result in Anabas testudineus. According to Aloo et al. (2004), the main reason for the differences in parasitic load with sex is physiological. In the present study, it was found that the prevalence and intensity of parasites of different groups varied for sex of hosts.

Table 1. Prevalence and intensity of helminth parasites according to the sex of the host in Channa punctatus

\begin{tabular}{c|c|c|c|cc}
\hline Host Sex & $\begin{array}{c}\text { No. of host } \\
\text { examined }\end{array}$ & $\begin{array}{c}\text { No. of host } \\
\text { infected }\end{array}$ & $\begin{array}{c}\text { No. of } \\
\text { parasites }\end{array}$ & $\begin{array}{c}\text { Prevalence } \\
(\%)\end{array}$ & $\begin{array}{c}\text { Mean intensity } \\
\pm \text { SD }\end{array}$ \\
\hline Male & 52 & 18 & 27 & 34.61 & $1.5 \pm 1.21$ \\
Female & 28 & 08 & 11 & 28.57 & $1.375 \pm 0.99$ \\
\hline Total & 80 & 26 & 38 & 32.5 & $1.46 \pm 1.29$ \\
\hline
\end{tabular}

The prevalence of trematodes, cestodes, acanthocephalans and nematodes in Channa punctatus were $13.75 \%, 6.25 \%, 3.75 \%, 8.75 \%$ and their mean intensities were $1.64 \pm 0.67$, $1.6 \pm 0.55,1.0 \pm 0.00$ and $1.28 \pm 0.49$. The highest prevalence $(13.75 \%)$ and intensity $(1.64 \pm 0.67)$ were observed in trematodes.

The prevalence of Neopecoelina saharanpuriensis, Mesolecitha linearis, Asymphylodora tincae, Genarchopsis bangladensis were 3.75, 2.5, 2.5 and 05\% respectively, and their mean intensities were $1.66 \pm 0.58,1.5 \pm 0.71,1.5 \pm 0.71$ and $1.75 \pm 0.71$ respectively. The prevalence of Ditestolepis diphana, Sengasp.,Neoechinorhynchus tylosuri, Pallisentis sp.,Ascardia sp., Gnathostoma spinigerum were $2.5,3.75,1.25,2.5,6.25$ and $2.5 \%$ respectively and their intensities were $1.5 \pm 1.12,1.66 \pm 1.12,01 \pm 0.71,01 \pm 0.00,1.2 \pm 1.41$ and 1.5 \pm 2.12 respectively (Table 2). $N$. saharanpurensios was also found in the study of Basirullah (1973) and Chowdhury (1992) in C. punctatus. The trematode parasites Gnathostoma spinigerum was previously recorded from Nandus nandus by Nahida (1993) and Khanum (1997) in Bangladesh. Rahman \& Parween (2001) reported that seven species of helminth parasites from C. punctatus which disagree the present findings. It has been noticed that the parasites show distinct relation with the season. The present investigation was carried out for eight months not covering all the season year round. Perhaps this is one of the causes of getting new parasitic fauna than the previous investigation. 
Table 2. Prevalence and intensity of helminth parasites in host fishes, Channa punctatus

\begin{tabular}{|c|c|c|c|c|}
\hline Name of Parasites & $\begin{array}{l}\text { No. of host } \\
\text { infected }\end{array}$ & $\begin{array}{c}\text { No. of } \\
\text { parasites }\end{array}$ & $\begin{array}{c}\text { Prevalence } \\
(\%)\end{array}$ & $\begin{array}{c}\text { Mean intensity } \\
\pm \text { SD }\end{array}$ \\
\hline \multicolumn{5}{|l|}{ Trematoda } \\
\hline Neopecoelina saharanpuriensis & 3 & 5 & 3.75 & $1.66 \pm 0.58$ \\
\hline Mesolecitha linearis & 2 & 3 & 2.5 & $1.5 \pm 0.71$ \\
\hline Asymphylodora tincae & 2 & 3 & 2.5 & $1.5 \pm 0.71$ \\
\hline Genarchopsis Bangladensis & 4 & 7 & 5 & $1.75 \pm 0.71$ \\
\hline \multicolumn{5}{|l|}{ Cestode } \\
\hline Ditestolepis diphana & 2 & 3 & 2.5 & $1.5 \pm 1.12$ \\
\hline Senga sp & 3 & 5 & 3.75 & $1.66 \pm 1.12$ \\
\hline \multicolumn{5}{|l|}{ Acanthocephala } \\
\hline Neoechinorhynchus tylosuri & 1 & 1 & 1.25 & $1 \pm 0.71$ \\
\hline Pallisentis sp. & 2 & 2 & 2.5 & $1 \pm 0.00$ \\
\hline \multicolumn{5}{|l|}{ Nematoda } \\
\hline Ascaridia larvae & 5 & 6 & 6.25 & $1.2 \pm 1.41$ \\
\hline Gnathostoma spinigerum & 2 & 3 & 2.5 & $1.5 \pm 2.12$ \\
\hline
\end{tabular}

Total host examined $=80$

Table 3. Distribution of helminth parasites in different organs of Channa punctatus

\begin{tabular}{l|c|c|c|c|c}
\hline \multicolumn{1}{c|}{ Name of Parasites } & Stomach & Gill & $\begin{array}{c}\text { Body } \\
\text { cavity }\end{array}$ & Intestine & Total \\
\hline $\begin{array}{l}\text { Neopecoelina } \\
\text { saharanpuriensis }\end{array}$ & $2(40 \%)$ & 0 & 0 & $3(60 \%)$ & 5 \\
Mesolecitha linearis & $1(33.3 \%)$ & 0 & 0 & $2(66.7 \%)$ & 3 \\
Asymphylodora tincae & $1(33.3 \%)$ & 0 & $2(66.7 \%)$ & 0 & 3 \\
Genarchopsis Bangladensis & $2(28.6 \%)$ & 0 & 0 & $5(71.4 \%)$ & 7 \\
Ditestolepis diphana & 0 & $1(33.3 \%)$ & $2(66.7 \%)$ & 0 & 3 \\
Senga sp. & 0 & $3(60 \%)$ & $2(40 \%)$ & 0 & 5 \\
Neoechinorhynchus & 0 & 0 & 0 & $1(100 \%)$ & 1 \\
tylosuri & 0 & 0 & $1(50 \%)$ & $1(50 \%)$ & 2 \\
Pallisentis sp. & 0 & 0 & 0 & $6(100 \%)$ & 6 \\
Ascaridia larvae & 0 & 0 & 0 & $3(100 \%)$ & 3 \\
Gnathostoma spinigerum & $6(15.79 \%)$ & $4(10.53 \%)$ & $7(18.42 \%)$ & $21(55.26 \%)$ & 38 \\
\hline Total & &
\end{tabular}

Data showed in parenthesis are $6 \%$ of parasites

The parasites were found in stomach, gill, body cavity and intestine. Out of 38 parasites, $06(15.79 \%)$ were found in the stomach, $04(10.53 \%)$ were found in the gill, $07(18.42 \%)$ were found in the body cavity and $21(55.26 \%)$ were found in the intestine. The highest prevalence and intensity of parasites were observed in the intestine (Table 3). Ascaridia larvae remained free in the intestine. This observation was supported by Huq et al. (1983) who found this worm in the digestive tract of $C$. punctatus. The present investigation recovered the occurrences of Gnathostoma spinigerum inhabit in the intestine of examined host. Akther et al. (1997) and Nahida et al. (1994) also showed that the parasite 
infestation is higher in the intestine. Sarma (2012) also found the similar result during his study in three murrel host species. Khanum et al. (2011) also observed the maximum helminth infestation from intestine. Intestinal parasites inhabit the digestive activity of the host and indirectly inhabit vitamin and blood sugar metabolism and growth; parasites in the liver affect glycogen metabolism and growth (Rhode, 1993).

Both the prevalence $(45.23 \%)$ and mean intensity (1.52) were the highest in the intermediate length group $(10.1-15.1 \mathrm{~cm})$. The prevalence in small length group $(5-10 \mathrm{~cm})$ was $25 \%$ and in the largest length group $(15.2-20.2 \mathrm{~cm})$ it was $16.66 \%$. And the mean intensity was 01 in the small length group $(10.1-15.1 \mathrm{~cm})$ and 1.4 in the large length group $(15.2-20.2 \mathrm{~cm})$ (Table 4). Both the prevalence $(42.55 \%)$ and mean intensity (1.5) were the highest in the intermediate weight group (21-31gm). Prevalence and intensity were $33.33 \%$ and 01 respectively in the lowest weight group (10-20gm) and $14.81 \%$ and 1.5 in the largest weight group (32-42gm) respectively (Table 4). One major reason is that as the fish grows, the amount of food it consumes, which includes the larval stages of the parasites increases (Paling, 1965; Meshego, 1989; Davey \& Gee, 1976). According to Khanum \& Parveen (1997), parasite infestation usually followed a direct relationship with length of Macrognathus acculeatus and Mastacemelus armatus. They also mentioned that prevalence and intensity were comparatively higher in larger and intermediate size-group of fishes respectively. Rahman \& Parween (2001) reported maximum prevalence and mean intensity in intermediate size and smallest size group respectively in Heteropneustes fossilis, Channa punctatus and Colisa fasciatus. This later findings were also similar with the present findings. Nahar (1988) reported that the intermediate size group was more infected by the parasites than the smaller and larger size groups. It is also well known that the host age and the habitat of the host plays vital role in the differences of prevalence. Biology of parasites, intermediate hosts, host behavior and most vitally seasons probably have great effects on infestation of parasites on host. So, further investigation with large number of hosts from all over Bangladesh considering seasonal variation and other biological attributes may provide a complete record of the parasites of Channa punctatus.

Table 4. Prevalence and intensity of helminth parasites among different length and weight groups of host fish, Channa punctatus (both sexes)

Length Groups

\begin{tabular}{c|c|c|c|c|c}
\hline $\begin{array}{c}\text { Length } \\
(\mathrm{cm})\end{array}$ & $\begin{array}{c}\text { No. of host } \\
\text { examined }\end{array}$ & $\begin{array}{c}\text { No. of host } \\
\text { infected }\end{array}$ & $\begin{array}{c}\text { No. of } \\
\text { parasites }\end{array}$ & $\begin{array}{c}\text { Prevalence } \\
(\%)\end{array}$ & $\begin{array}{c}\text { Mean } \\
\text { intensity }\end{array}$ \\
\hline $5-10$ & 08 & 02 & 02 & 25 & 01 \\
$10.1-15.1$ & 42 & 19 & 29 & 45.23 & 1.52 \\
$15.2-20.2$ & 30 & 05 & 07 & 16.66 & 1.4 \\
\hline
\end{tabular}

Weight Groups

\begin{tabular}{c|c|c|c|c|c}
\hline Weight(gm) & $\begin{array}{c}\text { No. of host } \\
\text { examined }\end{array}$ & $\begin{array}{c}\text { No. of host } \\
\text { infected }\end{array}$ & $\begin{array}{c}\text { No. of } \\
\text { parasites }\end{array}$ & $\begin{array}{c}\text { Prevalence } \\
(\%)\end{array}$ & $\begin{array}{c}\text { Mean } \\
\text { intensity }\end{array}$ \\
\hline $10-20$ & 06 & 02 & 02 & 33.33 & 01 \\
$21-31$ & 47 & 20 & 30 & 42.55 & 1.5 \\
$32-42$ & 27 & 04 & 06 & 14.81 & 1.5 \\
\hline
\end{tabular}


Acknowledgements: This research was financed by research grant from Jahangirnagar University research project in 2013-1014.

\section{REFERENCES}

Afroz, T., Nabi, M.R. and Mostafa, G. 1999. The morphohistology of alimentary canal of Chapila, Gudusia chapra. Bangladesh J. Zoology.27: 51-55

Ahmed, A.T.A. and Rouf, A.J.M.A. 1981. Acanthocephalan parasites of freshwater and estuarine fishes of Bangladesh. Proc. $3^{\text {rd }}$. Nat. Zool. Conf. 118-125.

Akther, M. 1995. Helminth parasites and their associated histopathology in Anabas testudineusin Bangladesh. M.Sc. Thesis. Eden Mohila College, Dhaka, pp.99.

Akhter, M., D'Silva, J andKhatun, A. 1997. Helminth parasites of Anabas testudineus Bloch in Bangladesh. Bangladesh J. Zoology. 25(92): 135-138.

Alam, M.J., Rakibuzzaman, M., Hasan, M.M. 2010. Comparative study of endoparasite infestation in Channa punctatus collected from hatchery sewage lagoon. Natural Sciences, 8: 152-156

Aloo, P.A., Anam, R.O. and Mwangi,J.N.2004. Metazoon parasites of some commercially important fish along the Kenyan Coast.Western Indian Ocean. J. Mar. Sci 3(1): 71-78.

Bashirullah, A.K.M. 1973. A brief survey of the helminth fauna of certain marine and freshwater fishes of Bangladesh. Bangladesh J. Zoology. 1(1): 63-81.

Cable,R.M. 1977. An illustrated laboratory manual of Parasitology, $5^{\text {th }}$ ed. Burgess Publishing Company, Minneapolis, Minnesota.

Chandra, K.J. 1998. The anatomy and histology of the alimentary tract of perch, Perca fluviatilis ( L.), Progressive Agriculture, 9:157-162

Cheng, T. C. 1973. General parasitology.Academic press, London.

Chowdhury, A.K. 1992. Helminth parasite infestation of histopathological changes in snakehead fishes. M.Sc. Thesis. Department of Zoology, University of Dhaka, Dhaka.

Davey, J.T. and Gee,J.M. 1976. The occurance of Mytilicola intestinalis Steuer, an intestinal copped parasite of Mytilus, in the North - SouthWest of England. J.Mar. Biol. Assoc. 56:85-94.

Dogiel, V.A. 1964. General Parasitology, trans 1,2 Kabata, Oliver and Boyd. Edinburgh and London.

Gupta, S. P. 1953. Trematode parasites of freshwater fishes. Indian J. of helminthol.5: 1-8.

Harris, K. K., Gupta,A.K. and Agrawal,S.M. 1992. Pathophysiology of Epizootic Ulcerative syndrome in Channa punctatus. Journal of Parasitology and Applied Animal Biology.1(2): 125-130.

Hoffman, G. L. 1967. Parasites of North American freshwater fishes. Cambridge University Press, London, England, pp. 127-128.

Hussain, M.G. 2010. Freshwater fishes of Bangladesh: Fisheries, biodiversity and habitat. Aquatic Ecosystem Health and Management. 13(1): 85-93.

Huq, M. M., Hossain, M. S., Amin, M. R. and Islam, M. A. 1983. A survey on the helminth parasites of Lata (Channidae) in and around the Bangladesh Agricultural University Campus, Mymensingh. Bangladesh J. Agricult. Sci. 10: 67-72.

Khan, A. 1985. Phyllodistomum ritai, new species (Trematoda: Gorgoridae: Phyllodistominae) from a freshwaterfish of Kalri lake Sind, Pakistan. Proceeding of Parasitology.1:1-5.

Khanum, H. 1997. Study of helminth parasites in Nandus nandus and colisa fasciatus. M.Sc. Thesis. Department of Zoology, University of Dhaka, Dhaka. 
Khanum,H. and Parveen, S. 1997. Organal distribution and seasonal prevalence of endoparasitesin Macrognathus aculeatus and Mastacemelus armatus. Bangladesh $j$. Zool. 25 (1):15-21.

Khanum, H., Begum, N and Begum, A.2011. Seasonal Prevalence, Intensity and Organal Distributionof Helminth Parasites in Macrognathus aculeatus. Dhaka Univ. J. Biol. Sci. 20(2): 117-122.

Margolis, L., EschG.W., Holmes,J.C., Kuriris,A.M. and Schad,G.A. 1982.The use of Ecological term in parasitology (Report of an Adhoe committee of the American Society of Parasitologists).Journal Parasitology. 68:131-133.

Mashego, S.N. 1989. Nematode parasites of Barbus species in Lebowa and Venda. South Africa J. Wild. Res.9:35-37.

Nahar, N. 1988. Prevalence and intensity of helminth parasites of xenentodon cancila (hamilton, 1822) in relation to some of its biological aspect. M.sc. thesis. Eden Mohilla College, Dhaka.pp.178.

Nahida, K. 1993. Studies on the helminth parasites and histopathology of infested organ Nandus nandus (Hamilton, 1822).M.Sc. Thesis. Eden Mohila College, Dhaka, pp.178.

Nahida, T.K.,Khatun, A and D'Silva, J. 1994. The histopathology of infested organs in Nandus nandus (Hamilton, 1822).Proc. Ninth Zool. Conf. Bangladesh.pp.51-54.

Paling, J.E. 1965. The population dynamics of the Monogenean gill parasite Discocotyle sagittata Leuckart on the Windermere trout, Salmo trutta L. Parasitology.55:67-69.

Rahman, A.K.A. 1989. Freshwater fishes of Bangladesh. The Zoological Society of Bangladesh, pp. 189-191.

Rahman, M. R. and Parween, S. 2001. Parasites infestation in relation to length Heteropneustes fossilis, Channa punctatus and Colisa fascitatus.Univ. J. Zool. Rajshahi Univ.20: 53-56.

Rohde, K. 1993. Ecology of Marine parasites; An introduction to Marine Parasitology. $2^{\text {nd }}$ Edition. CAB international. 298 pp.

Sarma, K. 2012. Seasonal incidence of Helminth Parasite of three selected Murrel Fish Species of Assam. PhD Thesis. Department of Zoology, University of Gouhati, India.

Srivastava, S.J and Singh, R. 1994. Seasonal changes in the testes of a freshwater murrel, Channa punctatus. Naturalia, x19: 119-130.

Yamaguti, S. 1958. Systema Helminthum, Vol. I, Interscience Publisher, New York, pp. 1575.

Yamaguti, S. 1963. Systema Helminthum, Vol. IV, Interscience Publisher, New York, pp. 421. 